\title{
Analiza odabranih članaka o napadu kemijskim oružjem u Siriji u hrvatskim i njemačkim elektroničkim medijima
}

\author{
Mirela Holy* \\ Nikolina Borčić** \\ Diana Tomić***
}

\section{SAŽETAK}

Rat u Siriji velika je prijetnja globalnoj sigurnosti, prepleteno polje vitalnih geopolitičkih interesa najvažnijih svjetskih sila - SAD-a i Rusije te njihovih saveznika. Rusija se politički $i$ vojno pozicionirala na strani režima sirijskog predsjednika al-Assada protiv pobunjenika, dok je pozicija SAD-a i članica NATO-a ambivalentna. Osuđuje se nedemokratski režim sirijskog predsjednika i zahtijeva njegov opoziv te se istovremeno osuđuje teroristička prijetnja ISIS-a koji se stopio sa sirijskim pobunjeničkim pokretom. Korištenje kemijskog oružja u Siriji u travnju 2017. prijetilo je eskalacijom u otvoreni ratni sukob SAD-a i NATO-ovih saveznica s Rusijom, a to je bilo vidljivo i putem propagandnog djelovanja $u$ medijima. S obzirom na činjenicu da se "proizvodnja pristanka” za politička rješenja i ratna djelovanja postiže korištenjem propagande, u radu se analizirao sadržaj elektroničkih medija na temu napada kemijskim oružjem u Siriji u dvjema članicama NATO-a, Njemačkoj i Hrvatskoj, odnosno je li se koristila

* Dr. sc. Mirela Holy, Veleučilište VERN'

Mirela Holy, Ph.D., VERN' University of Applied Sciences, Croatia; E-Mail/Email

Address: mirela.holy@vern.hr; Broj telefona/Phone Number: 01/4825 910

** Dr. sc. Nikolina Borčić, Veleučilište VERN'

Nikolina Borčić, Ph.D., VERN' University of Applied Sciences, Croatia; E-Mail/Email

Address: nikolina.borcic@vern.hr; Broj telefona/Phone Number: 01/4881 830

*** Doc. dr. sc. Diana Tomić, Filozofski fakultet Sveučilišta u Zagrebu

Asst.Prof. Diana Tomić,Ph.D., Faculty of Humanities and Social Sciences, University of Zagreb; E-Mail/Email Address: dtomic@ffzg.hr; Broj telefona/Phone Number: 01/4092 097 
propaganda prilikom izvještavanja o trima događajima ili pseudo-događajima, povezanih s korištenjem kemijskog oružja.

Ključne riječi: Sirija, kemijsko oružje, Hrvatska, Njemačka, ratna propaganda, mediji

\section{UVOD}

Tema rada je analiza medijskog prikaza ratnog događaja u Siriji u odabranim hrvatskim i njemačkim elektroničkim medijima. Polazišna pretpostavka jest da u stvaranju medijskog diskursa ne postoji objektivna istina, nego se radi o percepciji i interpretaciji medija te recepciji i interpretaciji publike (Jäger, 2004, 2007). Svaki diskurzivni događaj pritom u sebi nosi suodnos moći i nemoći, posebice kada je riječ o ideološkim stajalištima. Medijsko kreiranje poruka o ratnom sukobu, odnosno informacija ili izvještaja s bojišta, nije neutralno, nepristrano i objektivno, nego je temeljeno na emocionalnim argumentima. Gilbert $(1999,2001,2004)$ naglašava utjecaj emocija u argumentaciji prikazanoga diskurzivnog događaja, bilo apelom na primateljeve emocije i vrijednosti ili putem strukture samog argumenta kako ga iznosi pošiljatelj. Takvi argumenti obiluju emocionalno nabijenim riječima (engl. loaded language) koji, prema Herbst (2003), doprinose stvaranju senzacionalističkog konteksta te utječu na privlačnost sadržaja (Dor, 2003). Emocionalno nabijen jezik uključuje emocije, tj. određene vrijednosti kod publike (Weston, 2000). Takav jezik dominira u tekstovima o političkim temama, s posebnim naglaskom na tekstove o ratnim događanjima. Stoga analiza u ovom radu uključuje emocionalne argumente i emocionalno nabijen jezik zbog njihova djelovanja na publiku. Način izvještavanja o ratnoj temi može biti indikator prevladavajućeg političkog stava o nekoj temi, posredno čak i ukazati na stanje medija u državi, jer daje uvid u mehanizme kreiranja aktualnog diskursa. Diskurs se pritom smatra „društvenom praksom medija kao institucija u korist članova neke zajednice u sustavu složene diskurzivne hijerarhije različitih razina apstraktnosti i općenitosti" (Zgrabljić, 2003: 60, usp. van Dijk, 1988, 1998).

Razvidno je kako se sukobi i ratovi paralelno vode na bojištu i u medijima. Rat u Siriji nije iznimka pa se rat, osim na sirijskom bojištu, vodi svakodnevno i u svjetskim medijima, a moguće je da se način medijskih prikaza razlikuje ovisno o stanju medija, lišenosti političkih utjecaja na izvještavanje i drugim indikatorima razine razvoja medijske politike u društvu. Rat u Siriji u velikoj se mjeri reflektira na političku situaciju i stabilnost Europske unije, posebice rješavanje gorućeg problema migracija, ali i borbe s terorizmom. Njemačka i Hrvatska nisu samo članice Europske unije (EU), već su i članice NATO saveza u kojem najveći utjecaj imaju upravo 
Analiza odabranih članaka o napadu kemijskim oružjem u Siriji u hrvatskim...

Sjedinjene Američke Države (SAD), koje su jedan od aktivnih protagonista rata u Siriji. Osim toga, pitanje kontrole nad izdašnim sirijskim naftnim izvorima i energetskom infrastrukturom nalazi se u direktnoj zoni njemačkih i hrvatskih strateških interesa. Sve prethodno spomenute činjenice mogu u velikoj mjeri utjecati na način medijskog izvještavanja o temi, odnosno utjecati na objektivnost izvještavanja. Njemački mediji su odabrani jer je uzeta u obzir činjenica da se njemačko društvo, kao i ono britansko, odlikuje dugom tradicijom javnih medija (Zgrabljić, 2003), što može biti indikator i veće slobode u izvještavanju o ratnim temama. U tranzicijskom društvu kao što je hrvatsko, tradicija javnih medija znatno je kraća stoga je moguć veći utjecaj prevladavajućih političkih stavova na stvaranje teksta.

\section{Obilježja oružanog sukoba u Siriji}

Rat u Siriji traje od proljeća 2011. godine. Iako je rat počeo kao ekstenzija tzv. arapskog proljeća ili arapskog buđenja čiji je cilj bilo svrgavanje diktatorskog režima sirijskog predsjednika al-Assada, rat u Siriji nadrastao je taj početni impuls i postao prepleteno polje vitalnih geopolitičkih interesa najvažnijih svjetskih sila - Sjedinjenih Američkih Država i NATO-a s jedne, te Rusije, Kine i njihovih saveznika s druge strane. Cvrtila (2012: 49) upozorava da se ,za razliku od Tunisa, Egipta, Libije i Jemena u kojima je došlo do promjena na vrhu države i smjene vladajućih elita” stanje u Siriji ,zakompliciralo i ušlo u fazu krvavih obračuna”. Rat u Siriji, zbog izbjegličke krize i terorističkih akcija iniciranih od strane tzv. Islamske države Iraka i Sirije (ISIS), diljem Europe nadrastao je okvire bliskoistočnog problema i postao gorući europski, ali i globalni problem. Kada se tome pribroji i isprepleteno polje geopolitičkih, prvenstveno energetskih interesa cijelog niza država (Saudijske Arabije, Turske, Irana, SAD-a i Rusije), stječe se dojam da ne postoji stvarna volja za postizanjem političkog konsenzusa globalnih sila koji je nužan za okončanje ovog iznimno opasnog sukoba.

Eskalacija sukoba u Siriji pretvorila je građanski rat na kontinuirano nestabilnom području Bliskog istoka u gotovo otvoreni sukob vojnih velesila. Rusija se jasno politički i vojno pozicionirala na strani režima sirijskog predsjednika al-Assada. Pozicija SAD-a i članica NATO-a je ambivalentna. Naime, Zapad istovremeno osuđuje nedemokratski režim predsjednika al-Assada i zahtijeva njegov opoziv, ali i osuđuje terorističku prijetnju islamističkih pobunjenika koji su preuzeli sirijski pokret otpora. Činjenica je da se stanje u Siriji izuzetno zakompliciralo jačanjem ISIS-a, terorističke organizacije koja je gotovo u potpunosti preuzela pobunjeničku stranu u sirijskom sukobu. Napoleoni (2015) upozorava na predrasude i neznanje o sirijskom sukobu koji prevladavaju u zapadnim državama i koji se svode na percepciju Islamske države kao „anakrone organizacije” koja „želi vratiti kazaljke sata una- 
trag”. Međutim, ISIS su iznjedrile „globalizacija i moderna tehnologija” te „njena modernost i pragmatizam". Modernost ISIS-a vidi se i iz uspješnog korištenja propagande putem različitih društvenih mreža, posebno Facebooka i Twittera. Napoleoni (2015: 16) naglašava da je Islamska država analizirala ,propagandnu mašineriju koju su koristile američka i britanska administracija kako bi opravdale preventivni napad na Irak 2003.” te je stvorila ,jednako lažne mitologije s ciljem preobraćivanja, novačenja i prikupljanja sredstava po cijelom muslimanskom svijetu".

Razvidno je kako sukob u Siriji ima obilježja posredničkog rata, odnosno borbe „trećih strana u ime velikih svjetskih sila" (Napoleoni, 2015: 134), a to podrazumijeva vitalnu zainteresiranost SAD-a i Rusije za ishod ovog sukoba. No, rat u Siriji iskaz je „zamjenskih ratova” i regionalnih sila poput Turske, Saudijske Arabije i Irana (Bilandžić, 2015). Središnji motiv ovog rata su energetski geopolitički interesi.

Svjetski mediji intenzivno su izvještavali o napadu kemijskim oružjem koji se dogodio 4. travnja 2017. na području Kan Šejkuna u sirijskoj pokrajini Idlib. Ovo nije jedini napad kemijskim oružjem koji se dogodio tijekom rata u Siriji. Za Siriju se dugo pretpostavljalo da posjeduje kemijsko oružje, a Sirija je to i priznala 2012. No, i za sirijsku oporbu potvrđeno je posjedovanje te korištenje kemijskog oružja. U ožujku 2013. na temelju odvojenih zahtjeva sirijskih vlasti i nekoliko zapadnih država UN je počeo istraživati sumnje o korištenju kemijskog oružja u Siriji (Trapp, 2017: 363). U razdoblju od ožujka 2013. do ožujka 2017. UN je dokumentirao 25 incidenata u kojima je korišteno kemijsko oružje, a za 20 od tih incidenata utvrđeno je da su inicirani od snaga pod kontrolom sirijskih vlasti. Napad na području Kan Šejkuna nije bio uključen u ovo izvješće (Brooks et al., 2018).

\section{Medijski aspekt ratnog izvještavanja}

Mediji danas nisu samo čimbenik prijenosa informacija, nego su aktivan faktor u konstrukciji društvene, političke, ekonomske, kulturne i svake druge realnosti. Medijski prikaz oružanog sukoba može utjecati na javnost koja zahtijeva rješavanje krize, no ujedno se koristi u propagandne svrhe odabirom načina izvještavanja (Čerina, 2012: 105-106). Svjetski mediji često ne informiraju prenoseći cjelovitu sliku o ratu protiv terorizma, a svjesno usmjeravana argumentacija može služiti kao mehanizam za opravdavanje određenih vojnih misija (Čerina, 2012: 102). Sve to ima utjecaj na oblikovanje argumentacije u medijskom diskursu, pri čemu je naglasak na emocionalnim argumentima, odnosno emocionalnim apelima i emocionalno nabijenom jeziku kojim se izvještava o pojedinom događaju.

Korištenje propagande u ratne i političke svrhe nije ništa novo. Njemački kancelar von Bismarck (1815. - 1898.) još je u 19. stoljeću, prije pojave moderne propagande i masovnih medija, izjavio da se ,najviše laže poslije lova, tijekom rata i prije 
Analiza odabranih članaka o napadu kemijskim oružjem u Siriji u hrvatskim...

izbora" (Rupčić, 2007). Ratovi se vode oružjem, ali i informacijama. Iako termin propaganda ima iznimno negativnu konotaciju, činjenica je da mnogi teoretičari odnosa s javnošću smatraju da je danas znatno rašireniji termin odnosi s javnošću u stvari moderni sinonim za propagandu. ${ }^{1}$ Iako se crta razdjelnica između ovih dvaju termina postavlja tako da je propaganda jednosmjerna, a odnosi s javnošću dvosmjerna komunikacija (Škarica, 2012: 14), ambicija pošiljatelja poruke uvijek je utjecaj na ciljane publike.

Definicija propagande na koju se referira ovaj rad jest „plansko i namjerno djelovanje na promjenu i kontroliranje stavova” (Šiber, 2003: 144). Šiber objašnjava kako se propaganda provodi korištenjem cijelog niza različitih tehnika od kojih su neke usmjerene na emocionalnu komponentu stava (emocionalni sendvič, prijenos emocija, tehnika povezanih stavova, emocionalno nabijene riječi, zamjena imena, upotreba stereotipa, upotreba seksualnosti i erotike); a druge su usmjerene na osjećaj ugroženosti i nesigurnosti (upotreba autoriteta, popularnosti pojedinih osoba, manipulacija konformizmom, odnosno strahom od izoliranog mišljenja). Uporaba prethodno nabrojanih propagandnih tehnika ima za cilj proizvodnju pristanka ciljanih javnosti kojima se propagandist obraća. Medijski politički i ratni diskurs često sadrži emocionalni žargon. Emocionalni žargon posebice je učestao u ideološkom diskursu, a u tekstu je realiziran uporabom riječi u kontekstu mržnje, straha, ljubavi ili „opsesivnom ponavljanju verbalnih formula i automatskom udvostručenju atributa" (Ivas, 1988: 197).

Herman i Chomski u Proizvodnji pristanka $(1988)^{2}$ objašnjavaju kako proizvodnju pristanka u demokracijama, u kojima mediji nisu pod kontrolom države, omogućava koncentracija velikog broja privatnih medijskih izdanja u rukama tek nekoliko velikih medijskih korporacija. Drugi filter informacija u proizvodnji pristanka prema autorima jest utjecaj koji oglašivači imaju na sadržaj koji se objavljuje u medijima, a treći predstavljaju glavni izvori vijesti u masovnim medijima koji najčešće podrazumijevaju nekritičko preuzimanje podataka iz službenih izvora. Četvrti je filter u proizvodnji pristanka strah od sudskih tužbi protiv medijskih kuća, što rezultira autocenzurom, a posljednji je ideologija antikomunizma. Herman i Chomski (1988) tvrde kako propagandne kampanje mogu pokrenuti ili vlade ili jedna ili više glavnih medijskih korporacija.

Taylor (2009: 67-83) naglašava kako je „razumijevanje odnosa rata, sukoba i medija osnova za informirano demokratsko društvo". Na današnje izvještavanje, upozorava, snažno utječu agencije za strateške komunikacije koje ,neumorno rade kako bi oblikovale dnevni red globalnih medija, posebno u ratno vrijeme" (Taylor, 2009: 69). Uslijed propagandnog djelovanja vanjskih čimbenika, poput spomenutih agencija, mnogim usputnim promatračima ,nije uvijek jasno da su zapravo počela dva rata - 'stvarni rat' i 'medijski rat'" (Taylor, 2009: 82). No, ključno kritično pitanje 
za svaku zdravu demokraciju jest „koliko kvalitetno mediji izvještavaju o ratovima i sukobima" (Taylor, 2009: 83).

I Čerina (2012: 113) ističe da „vjerodostojno ratno izvještavanje podrazumijeva istinito i objektivno izvještavanje o patnjama i stradavanju civilnog stanovništva", ali da ratna propaganda s načinom izvještavanja i pozicioniranjem odabranih slika može manipulirati javnošću. Potencijali ove manipulacije multipliciraju se sve većim informiranjem građana putem društvenih mreža koje, zbog nepostojanja „medijskih vratara", omogućavaju potpuno neselektivnu objavu različitih informacija. DiStaso i McCorkindale (2012) naglašavaju kako su društvene mreže olakšale stvaranje i dijeljenje sadržaja, potaknule pojedince na javno iznošenje svojih mišljenja, omogućile korisnicima da se prezentiraju i stvore sljedbenike te ostvare mogućnost interaktivne komunikacije. Iako društvene mreže donose pozitivne iskorake u smislu izostanka cenzure i demokratizacije stavova i mišljenja u javnom medijskom prostoru, one povećavaju mogućnost plasiranja lažnih vijesti, a time i njihova utjecaja na javno mnijenje. EU je prepoznala opasnost lažnih vijesti koje se najčešće plasiraju putem društvenih mreža koje potom nekritički i bez provjere preuzimaju informativni portali, i uz pomoć kojih se manipulira građanima Europe. Stoga je EU krajem 2018. usvojila Akcijski plan za suzbijanje dezinformacija koji se sastoji od deset mjera koje se planiraju provesti tijekom 2019. godine s ciljem suzbijanja štetnog utjecaja lažnih vijesti, odnosno manipulativnih sadržaja u digitalnom prostoru, posebice na društvenim mrežama. Činjenica je da se nekritičkom objavom informacija, koje se plasiraju iz neprovjerenih izvora, olakšava propagandno djelovanje. Time se pogoduje i proizvodnji pristanka javnosti za politike koje vjerojatno ne bi dobile pristanak kada bi se izvještavanje temeljilo na većem broju poznatih i vjerodostojnih izvora.

Iako sukob svjetskih velesila oko rješavanja sukoba u Siriji nije prerastao u vojni, intenzivno se dalje vodi u političkim i diplomatskim centrima moći te u medijima i na društvenim mrežama. Izrazito intenzivne aktivnosti na proizvodnji pristanka za spomenute sukobljene opcije događaju se posredstvom elektroničkih medija, posebice internetskih informativnih portala, jer sve više raste značaj ovih medija kao važnog sredstva informiranja korisnika interneta.

\section{METODOLOGIJA}

Istraživanje u okviru ovog rada provedeno je na uzorku od ukupno 28 hrvatskih i njemačkih članaka o napadu kemijskim oružjem 4. travnja 2017. na području Kan Šejkuna u sirijskoj pokrajini Idlib, i s tim događajem povezanim američkim bombardiranjem te al-Assadovom reakcijom. Uzorak obuhvaća članke elektroničkih ekstenzija hrvatskih ${ }^{3}$ (24 sata; Novi list, Jutarnji list, Večernji list, Slobodna Dalma- 
Analiza odabranih članaka o napadu kemijskim oružjem u Siriji u hrvatskim...

cija) i njemačkih (Bild.de, Spiegel Online, Focus online, Die Welt, ZEIT Online) tiskovina. Jedinica istraživanja je članak. Tema članaka je sam napad, potom američko bombardiranje sirijske zračne baze 7. travnja 2017. te reakcija sirijskog predsjednika al-Assada.

Kriterij pri odabiru članaka bila je veličina članka i sadržajna obrada teme na način da uključuje opis događaja i prosudbu, a ne samo informaciju o događaju. Odabrani su novinski tekstovi na hrvatskom i njemačkom jeziku zbog članstva obiju država u NATO savezu, standarda kvalitete njemačkih tiskovina kao mogućeg uzora hrvatskim te, u konačnici, lingvističkog doprinosa akademskom diskursu na hrvatskom jeziku, gdje zbog poznavanja jezika dominiraju usporedbe s medijskim sadržajima na engleskom jeziku. Izdvojen je po jedan članak iz navedenih medija, objavljen na sami dan događaja (napad, američka reakcija, reakcija predsjednika), što znači da uzorak istraživanja čini ukupno 28 članaka s obzirom na činjenicu da Jutarnji list i Slobodna Dalmacija, izdanja Hanza medije, nisu objavile članke s Assadovim odgovorom.

Istraživanje u okviru ovog rada ima za cilj analizirati medijske prikaze napada kemijskim oružjem u Siriji koji se dogodio 4. travnja 2017. u svrhu identifikacije uporabe propagandnih tehnika. Preciznije, cilj je ovog rada analizirati i usporediti sadržaje objava hrvatskih i njemačkih elektroničkih medija na građi vezanoj uz napad kemijskim oružjem koji se dogodio 4. travnja 2017. na području Kan Šejkuna u sirijskoj pokrajini Idlib (izvještaji o samom napadu; izvještaji o američkom bombardiranju sirijske zračne baze dana 7. travnja 2017. te izvještaji o reakciji predsjednika al-Assada) kako bi se utvrdilo razlikuje li se pristup i način izvještavanja ovisno o mediju te jesu li analizirani mediji o sukobu izvještavali objektivno i istinito. Drugim riječima, nastoji se saznati mogu li se identificirati pokušaji manipulacije informacijama u cilju proizvodnje pristanka za američku, odnosno politiku NATO-a prema ratu u Siriji. Razlog odabira ovih povezanih događaja i pseudo-događaja (medijski odgovor al-Assada) jest taj što se iz njihove analize može uočiti moguća medijska pristranost prema sudionicima sirijskog sukoba te mijenja li se medijska argumentacija u prikazu samog čina, američkog odgovora koji nije odobren od strane UN-a, te al-Assadove medijske reakcije na američki napad. Istraživanje se temelji na sljedećim istraživačkim pitanjima:

(1) Čije tvrdnje dominiraju u analiziranim člancima te kako to utječe na tumačenje informacija?

(2) Na koji su način opisani protagonisti i koji je pristup sugeriran uporabom emocionalnih argumenata, odnosno za koje se informacije vežu emocionalni argumenti? 
Kvalitativna metodologija sve je češći analitički pristup društvenim sadržajima. Ramsenthaler (2013: 23) tvrdi da kvalitativan pristup analizi sadržaja započinje 20ih i 30-ih godina 20. stoljeća u okviru kvantitativne analize sadržaja velikog broja tekstova. U ovom se radu koristi kombinacija diskurzivne analize i analize sadržaja. Diskurzivne analize, prema Halmi et al. (2004: 35), odbacuju ,shvaćanje da je jezik samo jednostavno, neutralno sredstvo odražavanja ili opisivanja riječi”, već je ,analiza rasprave jedna od glavnih značajki za konstrukciju socijalne zbilje". Kvalitativna se analiza sadržaja prema Mayringu (2015: 50-114) temelji na modelu provedbe analize koji sadrži analizu konteksta i medija, teorijsko polazište analize, istraživačka pitanja, ciljeve istraživanja te definiranje uzorka istraživanja. Struktura članka slijedi opisani model analize.

Propaganda koja ima za cilj poticanje emocija kao načina kreiranja informacija česta je u diskursu rata. Takav diskurs neupitno sadrži u sebi ideologiju i strategiju uvjeravanja, a realizira se, između ostalog, emocionalnim argumentima i diskurzivnim strategijama kvalifikacije protagonista, posebice isticanjem kontrasta $m i$ versus oni (usp. van Dijk, 1998, 2006; Wodak i Meyer, 2009). Emocije u argumentima vrlo su bliske argumentacijskim pogreškama te tako ostvaruju tekstnu funkciju uvjeravanja (Groarke, 2010). Takve se strategije u političkom diskursu koriste u svrhu (de) konstrukcije osobnih i nacionalnih identiteta, međuodnosa moći, vrijednosnih uvjerenja, ideologija te, posljedično, odnosa nejednakosti u društvu. Ujedno takve diskurzivne strategije postaju platforma propagandnog djelovanja u svrhu proizvodnje pristanka.

Sukladno istraživačkim pitanjima, istraživanje uključuje identifikaciju izvora (novinska agencija ili drugi izvor), identifikaciju mi i oni dijelova izjava, potom su identificirane izjave analizirane iz semantičke i sintaktičke perspektive kako bi se identificirala uporaba emocionalnih argumenata te afektivno nabijenih riječi.

\section{REZULTATI ISTRAŽIVANJA I RASPRAVA}

Analiza je provedena na člancima objavljenima na mrežnim portalima pet hrvatskih i pet njemačkih tiskovina. ${ }^{4} \mathrm{U}$ tablicama 1 . i 2 . istaknuti su naslovi analiziranih članaka, a naslovi svojim sadržajem sugeriraju stav pojedinih medija. 
Analiza odabranih članaka o napadu kemijskim oružjem u Siriji u hrvatskim...

Tablica 1. Mediji i naslovi članaka hrvatskih tiskovina Table 1. Media and headlines of Croatian newspapers

\begin{tabular}{|c|c|c|c|}
\hline Medij & Sirijski napad & Američki odgovor & Assadov komentar \\
\hline Novi list & $\begin{array}{l}\text { "Žrtve povraćale i } \\
\text { gušile se": Bojni } \\
\text { otrovi bačeni na } \\
\text { sjeverozapadu Sirije, } \\
\text { među ubijenima i - } \\
\text { djeca - 4. travnja } \\
2017 .\end{array}$ & $\begin{array}{l}\text { Američka } \\
\text { veleposlanica pri } \\
\text { UN-u: Mogući novi } \\
\text { napadi na Siriju - } \\
\text { 7. travnja } 2017 .\end{array}$ & $\begin{array}{l}\text { Assad: Kemijski } \\
\text { napad u Idlibu } \\
\text { izmišljotina, uopće } \\
\text { nemamo takvo } \\
\text { oružje - 13. travnja } \\
2017 \text {. }\end{array}$ \\
\hline Jutarnji list & $\begin{array}{l}\text { STRAVIČAN } \\
\text { MASAKR } \\
\text { KEMIJSKIM } \\
\text { ORUŽJEM U SIRIJI } \\
\text { U zračnim napadima } \\
\text { na položaje } \\
\text { pobunjenika ubijeno } \\
\text { najmanje } 58 \text { osoba, } \\
\text { žrtvama izlazila } \\
\text { pjena na usta - } \\
\text { 4. travnja } 2017 .\end{array}$ & \begin{tabular}{|l|} 
TRUMPOVA \\
OSVETA ASSADU: \\
POČEO AMERIČKI \\
NAPAD NA SIRIJU \\
S ratnih brodova u \\
Sredozemnom moru \\
ispaljene krstareće \\
rakete prema \\
Assadovoj zračnoj \\
bazi - 7. travnja \\
2017.
\end{tabular} & I \\
\hline Večernji list & $\begin{array}{l}\text { Bojni otrovi bačeni } \\
\text { na sjeverozapadu } \\
\text { Sirije, najmanje } 58 \\
\text { žrtava } \\
\text { Sirijska nacionalna } \\
\text { koalicija, napad je } \\
\text { opisala kao masakr. } \\
\text { Kažu da je u napadu } \\
\text { ubijeno } 70 \text { ljudi, a } \\
\text { ranjeno više od } 200 \\
\text { - 4. travnja } 2017 .\end{array}$ & \begin{tabular}{|l} 
SAD napao zračnu \\
bazu u Siriji - \\
ispaljeno 59 \\
projektila, poginulo \\
šestero ljudi \\
Predsjednik SAD-a \\
Donald Trump \\
obratio se javnosti i \\
u televizijskom \\
prijenosu istaknuo da \\
je iz te baze izveden \\
napad kemijskim \\
oružjem - 7. travnja \\
2017.
\end{tabular} & $\begin{array}{l}\text { SVJETSKA } \\
\text { EKSKLUZIVA } \\
\text { Al-Assad: Europa se } \\
\text { neće zaštititi od } \\
\text { terorista jer ih } \\
\text { podržava } \\
\text { Hrvati su bolje od } \\
\text { ostalih Europljana } \\
\text { shvatili što se događa } \\
\text { u Siriji i nisu krivi za } \\
\text { pogreške svojih } \\
\text { vlada - 6. travnja } \\
2017 \text {. }\end{array}$ \\
\hline Slobodna Dalmacija & $\begin{array}{l}\text { Zbog kemijskog } \\
\text { napada u Siriji } \\
\text { zasjeda Vijeće } \\
\text { sigurnosti, Rusija se } \\
\text { protivi nacrtu } \\
\text { rezolucije }-5 \text {. } \\
\text { travnja } 2017 .\end{array}$ & \begin{tabular}{|l|} 
Svijet podijeljen \\
nakon američkog \\
napada na Siriju, \\
Moskva bjesni: Ovo \\
je akt agresije na \\
članicu UN-a! - 7 . \\
travnja 2017 . \\
\end{tabular} & I \\
\hline
\end{tabular}


Medij. istraž. (god. 25, br. 1) 2019. (5-31)

\begin{tabular}{|c|c|c|c|}
\hline Medij & Sirijski napad & Američki odgovor & Assadov komentar \\
\hline 24 sata & $\begin{array}{l}\text { Strava: Otrovnim } \\
\text { plinom ubili } 58 \text { ljudi, } \\
\text { među njima } 11 \text { djece } \\
\text { U zračnim napadima } \\
\text { na pokrajinu Idlib na } \\
\text { sjeverozapadu Sirije } \\
\text { u utorak su ubijeni } \\
\text { deseci ljudi. Sirijska } \\
\text { opozicija tvrdi da je } \\
\text { napad izveden } \\
\text { kemijskim oružjem. } \\
\text { Među mrtvima su i } \\
\text { djeca - 4. travnja } \\
2017 \text {. }\end{array}$ & $\begin{array}{l}\text { Trump je } \\
\text { bombardirao Siriju: } \\
\text { 'Taj se pokolj mora } \\
\text { zaustaviti' Tijekom } \\
\text { noći na zračnu bazu } \\
\text { u Siriji ispaljeno je } \\
59 \text { projektila s } \\
\text { razarača u } \\
\text { Sredozemnom moru. } \\
\text { Trump je kazao da je } \\
\text { vitalni nacionalni } \\
\text { sigurnosni interes } \\
\text { SAD-a spriječiti } \\
\text { upotrebu kemijskog } \\
\text { oružja - } \\
\text { 7. travnja } 2017 .\end{array}$ & $\begin{array}{l}\text { 'Mi nemamo } \\
\text { kemijsko oružje, a } \\
\text { taj napad je čista } \\
\text { izmišljotina' Još } \\
\text { 2013. godine riješili } \\
\text { cijelog kemijskog } \\
\text { arsenala (...), a čak i } \\
\text { da raspolažemo s } \\
\text { takvim naoružanjem } \\
\text { ne bismo ga nikada } \\
\text { upotrijebili, izjavio } \\
\text { je sirijski predsjednik } \\
\text { Bashar al-Assad } \\
\text { - 13. travnja } 2017 \text {. }\end{array}$ \\
\hline
\end{tabular}

Tablica 2. Mediji i naslovi analiziranih članaka njemačkih tiskovina ${ }^{5}$ Table 2. Media and headlines of German newspapers

\begin{tabular}{|c|c|c|c|}
\hline Medij & $\begin{array}{c}\text { Sirijski napad } \\
\text { (4. travnja 2017.) }\end{array}$ & $\begin{array}{l}\text { Američki odgovor } \\
\text { (7. travnja 2017.) }\end{array}$ & $\begin{array}{l}\text { Assadov komentar } \\
\text { (13. travnja 2017.) }\end{array}$ \\
\hline Bild.de & $\begin{array}{l}\text { Deseci mrtvih prilikom } \\
\text { napada kemijskim } \\
\text { oružjem u Siriji - } \\
\text { 4. travnja } 2017 \text {. } \\
\text { (Dutzende Tote bei } \\
\text { Giftgasangriff in Syrien) }\end{array}$ & $\begin{array}{l}\text { Trump je dopustio } \\
\text { bombardiranje zračne } \\
\text { luke u Siriji. Ovako je } \\
\text { protekao napad na } \\
\text { Assada - 7. travnja } \\
\text { 2017. } \\
\text { (TRUMP LÄSST } \\
\text { FLUGHAFEN IN } \\
\text { SYRIEN } \\
\text { BOMBARDIEREN } \\
\text { So lief der Angriff auf } \\
\text { Assad) }\end{array}$ & $\begin{array}{l}\text { Sirijski moćnik daje } \\
\text { sulud intervju. Assadova } \\
\text { otrovna propagnda - } \\
\text { 13. travnja } 2017 . \\
\text { (SYRIENS } \\
\text { MACHTHABER GIBT } \\
\text { IRRES INTERVIEW } \\
\text { Assads Giftgas- } \\
\text { Propaganda) }\end{array}$ \\
\hline $\begin{array}{l}\text { Spiegel } \\
\text { Online }\end{array}$ & $\begin{array}{l}\text { Napad raketama na } \\
\text { bolnicu s brojnim } \\
\text { žrtvama zbog kemijskog } \\
\text { otrova- } 4 \text {. travnja } 2017 . \\
\text { (Raketenangriff auf } \\
\text { Klinik mit } \\
\text { mutmaßlichen } \\
\text { Giftgasopfern) }\end{array}$ & $\begin{array}{l}\text { Reakcije na napad } \\
\text { kemijskim oružjem - } \\
\text { SAD napala bazu } \\
\text { zračnog oružja sirijske } \\
\text { vojske - 7. travnja } 2017 . \\
\text { (Reaktion auf } \\
\text { Giftgasangriff - USA } \\
\text { greifen Luftwaffenbasis } \\
\text { der syrischen Armee an) }\end{array}$ & $\begin{array}{l}\text { Sirijski moćnik Assad } \\
\text { - napad kemijskim } \\
\text { oružjem je „100\%-tna } \\
\text { konstrukcija“- } \\
\text { 13. travnja 2017. } \\
\text { (Syrischer Machthaber } \\
\text { Assad - } \\
\text { Chemiewaffenangriff zu } \\
\text { "hundert Prozent } \\
\text { konstruiert”) }\end{array}$ \\
\hline
\end{tabular}


Analiza odabranih članaka o napadu kemijskim oružjem u Siriji u hrvatskim...

\begin{tabular}{|c|c|c|c|}
\hline Medij & $\begin{array}{c}\text { Sirijski napad } \\
\text { (4. travnja 2017.) }\end{array}$ & $\begin{array}{l}\text { Američki odgovor } \\
\text { (7. travnja 2017.) }\end{array}$ & $\begin{array}{l}\text { Assadov komentar } \\
\text { (13. travnja 2017.) }\end{array}$ \\
\hline $\begin{array}{l}\text { Focus } \\
\text { Online }\end{array}$ & $\begin{array}{l}\text { Orginalan naslov teksta: } \\
\text { Deseci mrtvih prilikom } \\
\text { napada kemijskim } \\
\text { oružjem u Siriji-- } \\
\text { 4. travnja } 2017 . \\
\text { (Dutzende Tote bei } \\
\text { Giftgasangriff in Syrien) }\end{array}$ & $\begin{array}{l}\text { „Prelagano za popraviti“" } \\
\text { Trump brani odluku } \\
\text { protiv napada pîstā - } \\
\text { 7. travnja } 2017 . \\
\text { (“Zu leicht zu } \\
\text { reparieren”: Trump } \\
\text { verteidigt Entscheidung } \\
\text { gegen Beschuss von } \\
\text { Startbahnen) }\end{array}$ & $\begin{array}{l}\text { Assad tvrdi - napad } \\
\text { kemijskim oružjem je } \\
\text { „100\%-tna konstrukcija“ } \\
\text { - 13. travnja } 2017 . \\
\text { (Assad behauptet } \\
\text { Chemiewaffenangriff zu } \\
\text { "hundert Prozent } \\
\text { konstruiert”) }\end{array}$ \\
\hline Die Welt & $\begin{array}{l}\text { Obitelji su umrle u } \\
\text { krevetu“- 4. travnja } \\
2017 . \\
\text { („Familien sind in ihren } \\
\text { Betten gestorben) }\end{array}$ & $\begin{array}{l}\text { Baza ratnog } \\
\text { zrakoplovstva ,rastrgana } \\
\text { na komadiće“)-- } \\
\text { 7. travnja } 2017 . \\
\text { (Luftwaffenstützpunkt } \\
\text { al-Schairat ,in Stücke } \\
\text { gerissen“) }\end{array}$ & $\begin{array}{l}\text { Bashar al_Assad - } \\
\text { napad kemijskim } \\
\text { oružjem je,,100\%tna } \\
\text { konstrukcija,,-13. travnja } \\
2017 . \\
\text { (Baschar al-Assad: } \\
\text { Giftgasangriff »zu } 100 \\
\text { Prozent konstruiert«) }\end{array}$ \\
\hline $\begin{array}{l}\text { ZEIT } \\
\text { online }\end{array}$ & $\begin{array}{l}\text { Kemijski otrov je } \\
\text { proizveo paniku “- } \\
\text { 4. travnja } 2017 . \\
\text { (Giftgas erzeugt Panik") }\end{array}$ & $\begin{array}{l}\text { USA napada Assadovu } \\
\text { bazu ratnog } \\
\text { zrakoplovstva - } \\
\text { 7. travnja } 2017 . \\
\text { (USA greifen Assads } \\
\text { Luftwaffenbasis an ) }\end{array}$ & $\begin{array}{l}\text { Baschar al-Assad - } \\
\text { napad kemijskim } \\
\text { oružjem je } 100 \% \text {-tna } \\
\text { „konstrukcija““-13. } \\
\text { travnja 2017. } \\
\text { (Baschar al-Assad: } \\
\text { Giftgasangriff »zu } 100 \\
\text { Prozent konstruiert» }\end{array}$ \\
\hline
\end{tabular}

Ad 1) Čije tvrdnje dominiraju u analiziranim člancima te kako to utječe na tumačenje informacija?

Iz naslova u objema tablicama vidljivo je kako su eliptične konstrukcije često korištene u svrhu pozicioniranja prema sukobu. Njihova je temeljna funkcija privlačenje pažnje (apelativna funkcija) te pozivanje čitatelja na daljnje čitanje teksta (Vuletić, 2006, 2007).

Već letimičan pogled na tablicu 1. s rasporedom članaka prema hrvatskim medijima upućuje na zaključak kako dnevne novine koje se nalaze u vlasništvu Hanza medije (Jutarnji list i Slobodna Dalmacija) zauzimaju proamerički i pro-NATO stav, jer uopće nisu iznosile, obrađivale ili komentirale Assadov komentar na napad kemijskim oružjem i kasniji američki napad na sirijsku zračnu bazu.

Analiza sadržaja hrvatskih članaka pokazuje da je dominantan izvor informacija bila Hrvatska izvještajna novinska agencija (HINA) te, za članak u 24 sata, BBC i 
ruska agencija Ifax. HINA se oslanja na Deutsche Presse-Agentur (dpa) i Agence France Presse (AFP) koje spominje Novi list. Guardian, BBC i CNN spominju se u Jutarnjem listu. Večernji list također spominje BBC, dok se neimenovane agencije i Saudi Press Agency (SPA) spominju u Slobodnoj Dalmaciji.

Samo jedan od analiziranih tekstova donosi originalni intervju sa sirijskim predsjednikom al-Assadom koji je objavio Večernji list, potpisan imenom i prezimenom novinara koji je napisao intervju (Hassan Haidar Diab) i direktno prenosi izvor informacije.

Što se tiče osoba koje se u hrvatskim člancima spominju kao izvori, situacija je sljedeća: Ramija Abdela Rahmana, voditelja Sirijskog opservatorija za ljudska prava SOHR (za koji se s velikom sigurnošću može tvrditi da je front grupa ${ }^{6}$ sirijske oporbe koja koristi metodu astroturfinga ${ }^{7}$ ) citira se u Novom listu (4. travnja 2017.) i u Večernjem listu (4. travnja 2017.). Nikki Haley, ambasadorica SAD-a u UN-u; Antonio Guterres, glavni tajnik UN-a; Vladimir Šafronkov, ruski ambasador u UN-u; Sean Spicer, glasnogovornik Bijele kuće i Matthew Rycroft, britanski ambasador pri UN-u glavni su izvor informacija za Novi list (7. travnja 2017.). Tvrdnje al-Assada prenose se u Novom listu (13. travnja 2017.) i 24 sata (13. travnja 2017.), a Večernji list je 6. travnja 2017. objavio veliki intervju sa sirijskim predsjednikom. U hrvatskim medijima prenose se i izjave američkog predsjednika Donalda Trumpa i turskog ministra pravosuđa (Jutarnji list, 7. travnja 2017.), a u Večernjem listu od 7. travnja 2017. citiraju se: Donald Trump; predstavnik sirijske vojske; rusko ministarstvo vanjskih poslova; Talal al-Barazi, guverner pokrajine Homs; turska vlada; Viktor Ozerov, šef odbora ruskog senata za sigurnost i obranu; glasnogovornik britanske Vlade; Jean-Marc Ayrault, francuski ministar vanjskih poslova; Numan Kurtulmus, zamjenik turskog premijera; izraelski premijer Benjamin Netanyahu; američki državni tajnik Rex Tillerson; iranski ministar vanjskih poslova Bahram Qasemi te glasnogovornik Pentagona Jeff Davis. Slobodna Dalmacija oslanja se na: SOHR; Kim Won-sooa, visokog predstavnika UN-a za razoružanje; Mariju Zaharovu, glasnogovornicu ruskog ministarstva vanjskih poslova i Sirijsku vojsku (5. travnja 2017.) te na Konstantina Kosačeva, predsjednika odbora za obranu i sigurnost Ruskog parlamenta; glasnogovornika iranskog Ministarstva vanjskih poslova; Ahmada Ramadana, čelnika Sirijske nacionalne koalicije; ruskog predsjednika Putina; Putinova glasnogovornika Peskova; glasnogovornika britanske vlade; francuskog ministra vanjskih poslova Ayraulta te zamjenika turskog premijera Numana Kurtulmusa. Tabloid 24 sata poziva se na SOHR; Sirijsku nacionalnu koaliciju koja je oporbena skupina i sirijski vojni izvor (4. travnja 2017.) te na ruskog zastupnika Dmitrija Sablina; guvernera Talala Barazija; SOHR i predsjednike Trumpa i Putina (7. travnja 2017.).

Iz prethodne analize hrvatskih medija može se zaključiti sljedeće:

Vidljiv je izostanak reakcija hrvatskih političara na događaje u Siriji jer nijedan analizirani članak ne prenosi izjave hrvatskih političara s njihovom ocjenom recentnih 
Analiza odabranih članaka o napadu kemijskim oružjem u Siriji u hrvatskim...

događaja. Iz toga proizlazi da hrvatski mediji, usprkos strateškim energetskim interesima države povezanima s INA-inim izvorima nafte u Siriji, članstvu u EU i NATO-u te višekratno izraženim sumnjama da je Hrvatska prodavala oružje sirijskim pobunjenicima, ne smatraju Hrvatsku aktivnim čimbenikom u sirijskom sukobu.

Jutarnji list najpristraniji je u izvještavanju jer, iako kao i svi drugi analizirani hrvatski mediji koristi HINA-u kao glavni izvor informacija, ne prenosi izjave i stajališta Vlade Sirije, Rusije ili njihovih partnera Irana i Kine. U članku od 4. travnja 2017. Jutarnji list prenosi HINA-u koja prenosi Guardian i BBC, a Guardian iznosi tvrdnje SOHR-a. BBC citira neimenovane liječnike iz napadnutih bolnica iz čega je vidljiv pozitivan odnos Jutarnjeg lista prema sirijskoj oporbi. U člancima iz Jutarnjeg lista u potpunosti je izostavljena druga strana priče, a iz naslova članaka u Jutarnjem listu iščitava se proamerička pozicija.

Slobodna Dalmacija, iako dio Hanza medije, zauzima objektivniju poziciju od one Jutarnjeg lista. Već sami naslovi članaka u Slobodnoj Dalmaciji to sugeriraju, ali i izvori na koje se članci pozivaju. U prvom članku iz Slobodne Dalmacije, premda se putem HINA-e prenose agencije koje citiraju SOHR, citiraju se dužnosnik UN-a, glasnogovornica ruskog ministarstva vanjskih poslova te sirijska vojska. U drugom članku, koji također prenosi HINA-u, navodi se velik broj izvora koji dolaze s obiju sukobljenih strana. Sadržaj članaka iz Slobodne Dalmacije daleko je objektivniji, a zastupljena su stajališta svih uključenih strana.

U analiziranim člancima iz Novog lista argumentacija se gradi na navođenju sirijske oporbe i SOHR-a, većeg broja zapadnih dužnosnika, ali i ruskog veleposlanika pri UN-u te predsjednika al-Assada, što znači da je u tekstovima iz Novog lista identificirana zastupljenost oba pristupa sukobu. Novi list 13. travnja 2017. u članku ",Assad: Kemijski napad u Idlibu izmišljotina, uopće nemamo takvo oružje” prenosi tvrdnje sirijskog predsjednika prema kojima Sirija ne posjeduje kemijsko oružje od 2013. Također se na neutralan način prenose dijelovi intervjua koji je al-Assad dao Agenciji France Presse (AFP), a u tekstu se njegove izjave ne komentiraju ni na pozitivan, ni na negativan način.

U prvom članku objavljenom u 24 sata dominiraju tvrdnje sirijske oporbe. Demanti sirijske vlade spomenut je u jednoj rečenici na kraju teksta iz čega je vidljiv pozitivniji odnos prema oporbi nego li prema vladinim snagama. Drugi i treći članak neutralniji su i objektivniji. U drugom su zastupljena stajališta svih uključenih strana, a u trećem se prenose dijelovi intervjua koji je al-Assad dao agenciji France Presse tako da se ne komentiraju njegove izjave. Osim toga, 24 sata u drugom članku poziva se na BBC i rusku agenciju Ifax.

Večernji list, ukupno gledajući, od svih analiziranih medija nudi najneutralniji prikaz sirijskih događaja. Iako većim dijelom prvog članka dominiraju tvrdnje sirijske oporbe, a demanti sirijske vlade spomenut je samo u jednoj rečenici na kraju teksta, što 
ukazuje na pozitivniji odnos prema sirijskoj oporbi no prema vladinim snagama, $\mathrm{u}$ drugom su članku neutralno i objektivno zastupljena stajališta svih uključenih strana. Osim toga, Večernji list prenosi direktnu informaciju od ključnog protagonista sukoba u Siriji, predsjednika al-Assada objavom intervjua. Iako Assad u intervjuu iznosi svoje viđenje rata u Siriji koje je osobno, a time i subjektivno, postiže se cilj informiranja javnosti o stajalištima svih uključenih strana, posebice protagonista.

Iz tablice 2. vidljivo je kako su sve analizirane njemačke tiskovine prenijele informacije o svim događajima, što već na prvi pogled sugerira objektivniji pristup. Analiza članaka na njemačkom jeziku obuhvaća po tri članka sa svakog portala. Der Spiegel informira o svim trima temama. U članku o kemijskom napadu kao izvori se navode agencija Agence France Presse (AFP), aktivisti (svjedoci) iz sirijskog grada Kan Šejkuna. Članak donosi da su svjedoci ujedno i posrednici fotografija, video uradaka i izvještaja iz Kan Šejkuna. Kao neposredan izvor navode se pripadnici UN-a. U tekstu o američkom napadu kao izvori se citiraju riječi američkog predsjednika Trumpa, sirijska državna televizija, svjedok (Talal al-Barazi) koji telefonski daje izjavu agenciji AFP. Nadalje se navode SOHR, ruska informativna agencija RIA, neimenovani pripadnici američke vojske i američki ministar vanjskih poslova Rex Tillerson. U opremi članka stoje sljedeće agencije kao izvori informacija: $\mathrm{max} / \mathrm{syd} / \mathrm{vme} / \mathrm{mho} / \mathrm{dpa} /$ Reuters/AFP.

Das Bild je, nalik hrvatskom 24sata, najčitaniji njemački tabloid. Iz tablice broj 2. razvidna je uporaba emocionalno nabijenih riječi (npr. deseci mrtvih, napad, dopustiti bombardiranje, moćnik, sulud), naslovi su bombastični, a pristup temi može se opisati senzacionalističkim. U opremi članka o napadu 4. travnja 2017. ispod fotografije nalazi se temeljni izvor informacija, a to je Edlib Media Center ${ }^{8}$ AFP te njemačka novinska agencija dpa. Edlip Media Center sirijska je protuvladina aktivistička grupa koja je putem američkih, francuskih i njemačkih novinskih agencija distribuirala fotografije s mjesta događanja, a koje su ujedno i dokaz događanja. Izvori informacija su SOHR, a u samom se tekstu o napadu citiraju izjave američkog ministra vanjskih poslova i američkog predsjednika, potom izjava premijerke Merkel o nužnosti osude događaja, izjava britanskog ministra vanjskih poslova Johnsona i sirijski general koji je želio ostati neimenovan. Političke su izjave u smjeru potpore američkom pristupu, a vjerodostojnost im daje navođenje autora izjava, političara/ki na najvišim funkcijama. Takav potporanj tezi predstavlja argument autoriteta, a smatra se, jednako kao i iznošenje brojeva, snažnim dokazom (Weston, 2000). Kao dokaz izjave sirijske vladine teze o tome kako nije upotrijebljen bojni otrov, navodi se izjava neimenovanog sirijskog generala. U članku o američkom napadu sadržaj se temelji dominantno na informacijama agencije Reuters. U članku se navode izvori koji dolaze s obiju sukobljenih strana. Pritom sirijsku vladinu stranu ,zastupaju” svjedoci koji se navode imenom i prezimenom, sirijski ministar in- 
Analiza odabranih članaka o napadu kemijskim oružjem u Siriji u hrvatskim...

formacija, izvor iz sirijske vojske, izjava guvernera sirijske pokrajine Homsa alBarazija. Članak također prenosi izjavu emitiranu na sirijskoj državnoj televiziji o „američkoj agresiji na vojne ciljeve”. U tekstu je navedena i izjava ruskog predsjednika Putina koji napad klasificira kao „,napad na suverenu državu” te izjava Ozerova, predsjednika odbora za obranu i sigurnost Vijeća Federacije gornjeg doma Ruskog parlamenta ruskoj novinskoj agenciji RIA, a navodi se i iranski stav.

Američku stranu zastupaju glasnogovornica Pentagona, navode se izjave američkog predsjednika Trumpa, potom izjava francuskog ministra vanjskih poslova Ayraulta. Potporu američkom napadu u tekstu daje i turska Vlada. U izjavi zamjenika premijera Kurtulmana televizijskom kanalu Fox TV navodi se kako „međunarodna javnost treba stajati na suprotnoj strani Assadovom barbarstvu". Nadalje se citira izjava američkog ministra vanjskih poslova Tillersona, izjava mirovnog posrednika UN-a za Siriju De Mistura. Od izvora s televizije prenose se izjave prikazane na CNN-u. U članku koji donosi reakciju al-Assada na napad, od agencijskih izvora citiraju se francuska novinska agencija AFP, ruska agencija RIA i Reuters. U tekstu se prenose izjave emitirane na sirijskoj državnoj televiziji, izjava glasnogovornika međunarodne koalicije, pukovnika američkog ratnog zrakoplovstva Dorriana koju je dao novinskoj agenciji Reuters. Navodi se izjava neimenovanog predstavnika ruskog ministarstva obrane agenciji Ria o tome kako su ruske vojne snage poslale dronove $\mathrm{u}$ regiju s ciljem ispitivanja stanja.

Analiza pokazuje kako Bild koristi izvore s obiju strana, a snažnija potpora američkom stavu realizira se navođenjem izjava najviše rangiranih političkih dužnosnika o situaciji u Siriji. Analizirani članci objavljeni na internetskim portalima Focus, Die Zeit i Die Welt pokazuju homogen stav njemačke medijske javnosti - potporu američkom stavu. Svi analizirani članci navode izvore obiju sukobljenih strana, čime se postiže objektivnost i vjerodostojnost. Agencijski izvori u svim su analiziranim člancima, kako zapadne novinske agencije (apa, AFP, Reuters) tako i ruske novinske agencije RIA i TASS. Focus online u tekstu o napadu kemijskim oružjem navodi izjave američkog ministra vanjskih poslova Tillersona, britanskog ministra vanjskih poslova Johnsona, službeni stav francuske Vlade, izjave aktivista SOHR-a i pripadnika Organizacije za zabranu kemijskog oružja (OPCW). U članku koji je objavljen 7. travnja kao izvor se navodi tweet predsjednika Trumpa, a kao protuteža američkom stavu članak prenosi izjavu ruske novinske agencije TASS o ciljevima ruske vojne jedince te izjavu glasnogovornika ruske Vlade Peskova agenciji Interfax. Tekst jasno navodi podršku službene ruske politike sirijskoj vladinoj politici.

Njemački tjednik der Spiegel u svrhu postizanja objektivnog i vjerodostojnog izvještavanja navodi i izjavu iranskog predsjednika Rouhanija, koja je emitirana na iranskoj državnoj televiziji, a kojom Rouhani, ne imenujući predsjednika Trumpa imenom, navodi kako on (Trump) ima u Siriji potporu terorista. Kao potporu proame- 
ričkom stavu prenose se izjave američkih i zapadnoeuropskih dužnosnika kao glavnih izvora informacija. Focus prenosi izjavu al-Assada pozivajući se na agencijske izvore njemačke agencije dpa te francuske agencije AFP, a naslovom ističe izjavu al-Assada „100\% konstruirano”. Iz analiziranih članaka može se zaključiti da Focus Online nastoji zadržati objektivan i neutralan pristup temi, no iz tekstova se vidi diskretno zauzimanje proameričke pozicije.

Portal dnevne tiskovine die Welt $\mathrm{u}$ svojim se člancima poziva na informacije posredovane putem agencija AFP i dpa. Kao protagonisti informacija navode se SOHR i svjedok događanja Hasem Schehwan koji je dao izjavu Agenciji France Presse (AFP). Kao argumenti autoriteta u svrhu potpornja američkom pristupu navode se izjave dužnosnika američke Vlade, njemačke premijerke Merkel, francuskog predsjednika Hollandea, Frederice Mogherini, potpredsjednice EK i visoke predstavnice EU-a za vanjsku i sigurnosnu politiku. U tekstu nakon američkog napada objektivnost se postiže citiranjem Trumpa, potom guvernera sirijske pokrajine Homsa te SOHR-a. Tekst objavljen 13. travnja 2017. navodi izjave al-Assada novinskoj agenciji AFP. Nije prenesen cijeli intervju, no citiraju se njegove glavne poruke poput teze da je ,navodni napad kemijskim oružjem insceniran kako bi služio kao paravan za američki napad na sirijsku vojsku" te se u naslovu i u tekstu ponavlja Assadova teza da je napad kemijskim oružjem $100 \%$ insceniran.

Ad 2) Na koji su način opisani protagonisti i koji je pristup sugeriran uporabom emocionalnih argumenata, odnosno za koje se informacije vežu emocionalni argumenti?

Jutarnji list intenzivno koristi emocionalne apele prilikom izvještavanja o napadu kemijskim oružjem sirijske vojske. Jutarnji list nije objavio Assadove komentare, ali ne nedostaju članci poput ovog naslova s američkim viđenjem napada: „AMERIKANCI I EU NE DVOJE TKO JE KRIVAC ZA JEZIVI KEMIJSKI NAPAD U SIRIJI: Svijet se zgražava zbog Assadova poteza, a Rusi imaju svoju verziju priče"”. U svrhu naglašavanja emocionalno nabijene perspektive Jutarnji list koristi emocionalnu argumentaciju (glas autoriteta, diskurs žrtve) koja je, primjerice, vidljiva iz sljedeće tvrdnje:

(1) Mnogi su se ljudi gušili, povraćali ili su se onesvijestili, pripadnici hitnih službi su šmrkovima polijevali žrtve, a nekima je na usta izlazila pjena, kaže Opservatorij navodeći medicinske izvore koji su to opisali znakom da je izvršen napad plinom.

(Jutarnji list, 4. travnja 2017.)

Jutarnji list osigurava poziciju autoriteta navođenjem neimenovanih medicinskih izvora koji su utvrdili da je korišten plin, zabranjeni kemijski otrov. Pozicija je potpuno jasna - negativci su sirijska Vlada i vojska koje su izvele monstruozan zločin 
Analiza odabranih članaka o napadu kemijskim oružjem u Siriji u hrvatskim...

nad nevinim civilima i djecom. Podrazumijeva se da su simpatije medija na strani žrtava - sirijske oporbe koja je izvijestila o ovim zlodjelima.

Sličan pristup koristio je i Novi list u prvom od analiziranih članaka, intenzivnim korištenjem emocionalnih apela, $i$ to bez ograda prilikom navođenja izvora vijesti:

(2) Na napadnutom području Kan Šejkun u pokrajini Idlib žrtve bojnog otrova povraćale su i gušile su se... među ubijenima 11 djece... Aktivisti su na društvenim mrežama prikazali snimke tijela mrtve djece nagomilane na hrpu.

(Novi list, 4. travnja 2017.)

No, iz sadržaja ostalih dvaju članaka stječe se oprezniji dojam pa se tako u članku „Američka veleposlanica pri UN-u: Mogući novi napadi na Siriju” ne koriste emocionalni opisi stradanja civila, već su neutralno prenesene izjave dužnosnika UN-a i glasnogovornika Bijele kuće, a njihove se izjave ne komentiraju ni na pozitivan ni na negativan način. Novi list u dvama kasnijim člancima ograđuje se od čvrstog svrstavanja pa prilikom opisa napada kemijskim oružjem od sirijske vojske koristi prilog „navodno”.

I Slobodna Dalmacija forsira emocionalne apele, što je vidljivo iz sljedećeg citata:

(3) Upotreba kemijskog oružja je užasna i treba biti kažnjena jer je ratni zločin”, prenosi se izjava francuskog ministra vanjskih poslova Ayraulta koji je dodao "da Rusija i Iran moraju shvatiti da je besmisleno podupirati Assada.

(Slobodna Dalmacija, 7. travnja 2017.)

U prvom članku, onom od 5. travnja 2017., čitatelje se informira kako su sugestije Rusije da su civili otrovani oružjem pobunjenika gotovo svi odbacili tvrdeći da dokazi upućuju da je napad izvela sirijska vojska, čime se može iščitati pozicija MI kao onih na strani zapadnih saveznika, i ONIH - Sirije i Rusije. U članku se nigdje ne navodi koji to dokazi upućuju na to da je sirijska vojska izvela napad na civile i djecu i tko su to gotovo svi. Podrazumijeva se da se SVI odnosi na zapadne saveznike.

Večernji list, poput drugih analiziranih članaka iz hrvatskih medija, u prvom tekstu već u naslovu nekritički koristi emocionalne apele (bojni otrovi, najmanje 58 žrtava, masakr, ubijeno 70 ljudi, ranjeno više od 200). Iz samog sadržaja članka dodatno se intenzivira takva argumentacija, što je vidljivo iz sljedećih riječi:

(4) Najmanje 58 ljudi, među njima 11 djece, ubijeno je u zračnim napadima na pobunjenička područja na sjeverozapadu Sirije, objavio je SOHR... žrtve bojnog otrova povraćale su i gušile su se... Aktivisti su na društvenim mrežama prikazali snimke tijela mrtve djece nagomilane na hrpu. Sirijska nacionalna koalicija, inače oporbena skupina, opisala je napad kao 'masakr'.

(Večernji list, 4. travnja 2017.) 
Većim dijelom članka dominiraju tvrdnje sirijske oporbe, demanti sirijske vlade spomenut je samo u jednoj rečenici na kraju teksta. Iako autor prenosi tvrdnje bez komentara, iz cijelog je članka vidljiv pozitivniji odnos prema oporbi, no prema vladinim snagama.

24 sata je tabloid pa se iz naslova članaka o sirijskim događanjima vidi senzacionalistički pristup temi. U naslovima dominiraju emocionalno nabijene riječi poput strava, pokolj, otrovni plin, ubili djecu, a i u samom tekstu nastavlja se takva retorika:

(5) U zračnim napadima na pokrajinu Idlib na sjeverozapadu Sirije u utorak ubijeno najmanje 58 ljudi, od čega 11 djece. Napad je izvršen iz zraka, a u njemu je korišten toksični plin. Žrtve bojnog otrova povraćale su i gušile su se.

(24 sata, 4. travnja 2017.)

Kao i kod Večernjeg lista, iz cijelog je članka vidljiv pozitivniji odnos prema oporbi, no prema vladinim snagama.

Analiza članaka u njemačkom tabloidu Bild pokazala je potporanj stavovima preko emocionalne argumentacije uporabom izraza usmjeravanja mržnje i straha kao u:

(6) 'Jasno je kako Assad operira: brutalnim i očitim barbarstvom' - objasnio je američki ministar vanjskih poslova Rex Tillerson u utorak u Washingtonu u izjavi.

(Bild, 4. travnja 2017.)

U analiziranim člancima iz tiskovina Der Spiegel i Die Welt vidljiva je eksplicitna uporaba emocionalne argumentacije u svrhu usmjeravanja stavova, a time i manipulacije javnosti, što je vidljivo iz (2) i (3):

(7) Svjedoci šalju potresne slike, videa i izvješća iz Chan Schaichuna.

(Der Spiegel, 4. travnja 2017.)

(8) Ovo je jedan od najtežih napada otrovnim plinom u sirijskom građanskom ratu.

(Die Welt, 4. travnja 2017.)

Analizirani članci u tjedniku Die Zeit prenose izjave Kristin Helberg, politologinje i stručnjakinje za Bliski istok. Na taj se način potencira stručni diskurs koji, iako lišen senzacionalnosti i subjektivnosti, ne predstavlja u očima recipijenta objektivan stav vladajućih političara pa je pitanje ima li utjecaja na stavove javnosti. Analiza ostalih dvaju članaka tjednika Die Zeit pokazuje kako taj tjednik nudi neutralan prikaz sirijskih događaja. Premda većim dijelom prvog članka dominiraju stavovi koji su svojevrstan potporanj tvrdnjama proameričkih dužnosnika i sirijske oporbe, a demanti sirijske vlade se ne argumentira detaljno, u drugom članku su neutralno i objektivno zastupljena stajališta ključnih sukobljenih protagonista. Osim toga, Die Zeit prenosi informaciju od ključnog protagonista sukoba u Siriji, al-Assada suklad- 
Analiza odabranih članaka o napadu kemijskim oružjem u Siriji u hrvatskim...

no novinskim agencijama dpa, AFP Reuters. U tekstu koji prenosi dio intervjua alAssada navodi se njegovo viđenje rata u Siriji, ali i stavovi Putina, Kennetha Warda, američkog veleposlanika u Den Haagu i predstavnika Organizacije za zabranu kemijskog oružja (OPCW). Na taj se način postiže cilj objektivnog informiranja javnosti o stajalištima svih uključenih strana.

U svrhu manipulacije koriste se argumenti autoriteta navođenjem izjava vodećih zapadnih i američkih dužnosnika koji podupiru američki stav, a znakovit je i implicitan potporanj američkom stavu u tekstu objavljenom na portalu ZEIT ONLINE, u kojem se posredstvom riječi stručnjakinje objašnjava način postupanja Assadova režima, kao u (4) te citiranje izjava Donalda Trumpa koji koristi emocionalno nabijen jezik u svrhu isticanja posljedica djelovanja sirijske Vlade, kao u:

(9) Helberg: Teško je razumjeti da Assadov režim zapravo više može postići bombama. Uporaba barel bombi ili raketa u medijima se gotovo ni ne spominje, Assad tu ima otvorene ruke. Kemijski otrov zvuči puno drastičnije i zastrašuje javnost.

ZEIT ONLINE: Napad se dogodio na dan početka briselske konferencije o Siriji?

Helberg: To vremensko preklapanje je stvarno iritantno.

(Die Zeit, 4. travnja 2017.)

(10) Donald Trump je na novinarskoj konferenciji koja je nabrzinu sazvana za vrijeme susreta s kineskim predsjednikom Xi Jinpingom: (...) 'Pozivam večeras sve civilizirane nacije, zaustaviti klanje i krvoproliće u Siriji. Assad je ugasio život bespomoćnih muškaraca, žena i djece. To je bila polagana i brutalna smrt za mnoge, čak su i prekrasne bebe užasno ubijane u tom brutalnom barbarskom napadu.

(Bild, 7. travnja 2017.)

(11) Trump je imenovao napad na zračnu bazu 'temeljnim za nacionalnu sigurnost' svoje zemlje. 'Pozivam danas sve civilizirane nacije da nam se pridruže. " Krvoproliće mora stati. Ne može se poreći da je Sirija koristila zabranjen kemijski otrov, tako je američki predsjednik u kratkoj izjavi pojasnio, da se radi o ciljanom udaru na određene vojne zrakoplovne luke.

(Der Spiegel, 7. travnja 2017.)

(12) Trump je govorio o osveti za barbarske napade moćnika Bashar al-Assada.

(Die Welt, 7. travnja 2017.)

Iako je u analiziranim člancima na njemačkom jeziku dominantna potpora američkom stavu, tekstovi prenose i argumentaciju te kvalifikaciju obiju sukobljenih strana, navodeći pritom izjave ruskih političara kao u (13) i sirijskog predsjednika al- 
Assada kao u (14). U svrhu postizanja snažnijeg dojma, koriste se mehanizmi manipulacije kao što su ponavljanje, uopćenost, metaforičnost. Ti su jezični mehanizmi dominantni u medijsko-političkom diskursu kada se širu javnost želi uvjeriti u stav, a u ovom slučaju to možemo protumačiti kao uvjeravanje u objektivno i nepristrano informiranje o ratnom sukobu.

(13) 'Sva odgovornost kod vojne akcije je na leđima onih koji su započeli s tom upitnom i tragičnom akcijom' rekao je zamjenik ruskog veleposlanika pri UN-u Wladimir Safronkow.

(Der Spiegel, 7. travnja 2017.)

(14) Sirijski predsjednik Bashar al-Assad rekao je novinskoj agenciji AFP da je navodni napad kemijskim oružjem na Chan Scheichun 100\% konstruirana lažna bajka."

(Bild, 13. travnja 2017.)

\section{ZAKLJUČAK}

Iako je analiza hrvatskih i njemačkih odabranih elektronskih članaka pokazala da njemački mediji nastoje više od hrvatskih u medijskim prikazima napada kemijskim oružjem, američkog bombardiranja te al-Assadova odgovora koristiti metode istraživačkog novinarstva, koji podrazumijevaju prezentaciju stavova obiju strana i provjere izvora, svi analizirani mediji, i oni njemački i oni hrvatski, intenzivno koriste emocionalne apele koji upućuju na propagandne namjere. Analiza je pokazala veći interes njemačkih medija i politike za sirijski sukob jer su u njemačkim izvještajima, za razliku od hrvatskih, prisutne i izjave domaćih političara/ki.

Analiza članaka i kasnija rasprava odgovorila je na dva postavljena istraživačka pitanja te pokazala kako je u analiziranim člancima na hrvatskom i njemačkom jeziku prisutno intenzivno korištenje emocionalno nabijenih riječi poput bojni otrovi, žrtve, žrtve povraćale i gušile se, mrtva djeca, masakr, jezivi masakr, strava, stravičan masakr, ali i potenciranje osjećaja ugroženosti. Upravo se ovim tehnikama u bližoj i daljoj prošlosti nastojao proizvesti pristanak javnosti za određenu politiku, a nerijetko se u tome uspijevalo i u demokracijama jer za proizvodnju pristanka nije nužna državna kontrola nad medijima.

U pristranosti izvještavanja, odnosno zauzimanju proameričkog stava, u odnosu na sve ostale analizirane medije prednjači hrvatski Jutarnji list. Osim pristranosti argumentacije, Jutarnji list i Slobodna Dalmacija, mediji u vlasništvu Hanza medije, od svih analiziranih medija jedini nisu objavili al-Assadov odgovor, što pojačava dojam pristranosti ove medijske kuće.

U nekim člancima koji su izvještavali o američkom bombardiranju sirijske zračne luke emocionalni apeli koriste se kako bi se opravdao američki čin bombardiranja 
Analiza odabranih članaka o napadu kemijskim oružjem u Siriji u hrvatskim...

države članice UN-a bez suglasnosti UN-a. Prenose se dijelovi govora predsjednika Trumpa u kojima se opisuje strahota stradanja civila u Idlibu, posebice stradanje djece, što ukazuje na neuravnoteženo i neobjektivno izvještavanje. Naime, u izvještajima o napadu kemijskim oružjem nisu prisutni pokušaji koji bi sugerirali na pristranost prema sirijskoj ili ruskoj strani.

Analiziranim člancima zajedničko je planirano i usmjereno djelovanje s ciljem kontrole stavova javnosti, što je obilježje propagandnog djelovanja. To je, osim emocionalnih apela i potenciranja osjećaja ugroženosti, vidljivo i iz korištenja neprovjerenih informacija kao vjerodostojnih te iz dominacije tvrdnji jedne strane. Analizirani mediji, usprkos složenoj dinamici sirijskog sukoba, sugeriraju na zaključak da smo „Mi” zapadni saveznici, a na „našoj” strani su „,dobri pobunjenici, neimenovana sirijska oporba, civili i djeca”, a „Oni” su sirijski režim predsjednika al-Assada, Putinova Rusija i Iran. ISIS, koji je premrežio sirijski oporbeni pokret, u tom se pozicioniranju u pravilu ignorira kao nešto što nije dio jednadžbe.

Sukob oko energetskih interesa i učvršćivanje zona političkih interesa velikih sila, koji se manifestira kao posrednički i zamjenički rat u Siriji, mogao je eskalirati u otvoreni ratni sukob SAD-a i NATO-ovih saveznica te Rusije, a to je bilo vidljivo i iz djelovanja u medijima. Zbog toga je iznimno važno upozoravati na manipulativne tehnike kojima se putem masovnih medija nastoji proizvesti pristanak javnosti za mogući kasniji ulazak u otvoreni sukob. Razotkrivanje manipulacije informacijama u cilju proizvodnje pristanka za konkretnu politiku pokazuje da mediji ne ispunjavaju svoju temeljnu ulogu, objektivno informiranje javnosti, već služe skrivenim interesima.

Imajući na umu da se propaganda često služi izmišljanjem strahota koje čini suprotna strana u sukobu kako bi emocionalnim apelima proizvela pristanak javnosti, nužno je kritičko propitivanje svih vijesti koje nose takvu emocionalnu težinu, a njihova se vjerodostojnost temelji na izjavama, slikama ili videima jedne od uključenih strana ili njihovih front grupa. Zbog toga događaje u Siriji treba staviti pod iznimno kritičku lupu sve dok neovisna međunarodna tijela ne utvrde što se doista dogodilo 4. travnja 2017.

\section{BILJEŠKE}

1 U tom kontekstu o odnosu propagande i odnosa s javnošću govori Michael Kunczik u knjizi Odnosi s javnošću: „Po mom su mišljenju, sveukupno gledajući, propali svi pokušaji razlikovanja promocije, odnosa s javnošću i propagande“ ili „Ti pojmovni pokušaji razgraničenja su () semantičke igrarije jer između propagande i odnosa s 
javnošću nema nikakve razlike.“(2006: 12-13). Branko Hebrang u članku „Politička promidžba kao socijalna pojava“ (2012: 14) govori kako je „Edvard Bernays još () dvadesetih godina prošlog stoljeća u Sjedinjenim Američkim Državama preimenovao pomalo pejorativan izraz propaganda u odnose s javnošću“.

2 https://chomsky.info/consent01/ (pristup 4. listopada 2017.).

3 U Hrvatskoj nisu dostupni službeni statistički podaci o posjećenosti pojedinih portala elektroničkih verzija tiskovina (http://www.e-mediji.hr). U Saveznoj Republici Njemačkoj podaci se redovito navode na internetskoj stranici Das Statistik-Portal. Istraživanje stoga obuhvaća njemačke tekstove sukladno podacima na toj stranici (usp. https://de.statista.com/statistik/daten/studie/154154/umfrage/anzahl-der-visits-von-nachrichtenportalen/). U travnju 2017. radi se o sljedećim podacima online i mobilne posjećenosti portala: Bild. de (358,78 mil.); 2. Spiegel Online (220.95 mil.); 3. Focus online (168.93 mil.); 4. Die Welt (111.45 mil.); 5. ZEIT Online (60,59 mil.).

4 S obzirom na činjenicu da ove dnevne novine, odnosno njihove elektroničke ekstenzije ulaze u medijske glavne struje, a za razliku od nekih web informativnih portala, iz sadržaja članaka koje objavljuju moguće je donositi meritornije zaključke o pokušaju političkog utjecaja na kreiranje stavova javnosti o sirijskom sukobu, posebice imajući na umu da su najvećim dijelom preuzimane vijesti HINA-e, javnog informativnog servisa koji financijski još uvijek ovisi o državi. U obradu su uzeti članci koji tematiziraju navodni sirijski napad kemijskim oružjem dana 04. travnja 2017. na području Kan Šejkuna u pokrajini Idlib; članci koji tematiziraju američko bombardiranje zračne baze sirijske vojske dana 07. travnja 2017.; te članci koji prenose komentare/odgovore na intervju sirijskog predsjednika al-Assada.

5 internetske stranice analiziranih članaka navedene su u popisu literature.

6 Front grupe su lobističke grupe koje skrivaju svoju istinsku svrhu i podršku u cilju utjecanja na javnost ili na vladu bez otkrivanja njihove financijske veze s korporativnim ili političkim interesima. Stvaraju privid pouzdane organizacije koja služi javnosti, no front grupe zapravo služe svojim sponzorima. (Jakobsen, 2000)

7 Prema Rječniku urbanog nazivlja (engl. Urban dictionary) naziv astroturfing je ,metoda stvaranja male organizacije koja se predstavlja kao da zagovara neku ideju u cilju promocije određenog subjekta ili interesa (astroturfing 'igra' na široke mase jer se nastoji prikazati kao popularni pokret koji je izniknuo iz naroda, među običnim ljudima, ova metoda je dobila ime po marki umjetne trave Astro Turf).“ (http://www. urbandictionary.com/define.php?term=astroturfing)

8 U američkim tiskovinama je objavljena ista fotografija, a uz navođenja izvora i opisa autentičnosti. Tekst uz istu fotografiju, objavljen na portalu Chicago Tribune (usp. http://www.chicagotribune.com/ct-syria-gas-attack-death-toll-20170404-001-photo.html). 
Analiza odabranih članaka o napadu kemijskim oružjem u Siriji u hrvatskim...

\section{LITERATURA}

Bilandžić, M. (2015) "Ruska intervencija u Siriji: Kraj Islamske države i sirijskog režima ili novi postafganistanski okvir", Vojna povijest. https://vojnapovijest. vecernji.hr/vojna-povijest/rusi-u-siriji-kraj-islamske-drzave-1035357.

Brooks, J., Erickson, T.B., Kayden, S., Ruiz, R., Wilkinson, S. i F. M. Burkle (2018) "Responding to chemical weapons violations in Syria: legal, health, and humanitarian recommendations", Conflicts and Health, 12 (12). doi: 10.1186/ s13031-018-0143-3.

Cvrtila, V. (2012) “Sirija i Libija: što ih povezuje, a što dijeli?”, Političke analize, (12), 48-54.

Čerina, J. (2012) "Ratno izvještavanje u kontekstu suvremenih oružanih sukoba i novih medijskih tehnologija", Polemos, 15 (1), 101-117.

DiStaso, M. W. i T. McCorkindale (2012) "Social Media: Uses and Opportunities in Public Relations”, Global Media Journal, 5 (2), 75-82.

Dor, D. (2003) “On newspaper headlines as relevance optimizers", Journal of Pragmatics, 35 (5), 695-721. doi: 10.1016/S0378-2166(02)00134-0.

Gilbert, M. A. (2001) "Emotional messages”, Argumentation, 15 (3), 239-250.

Gilbert, M. A. (2004) "Emotion, argumentation and informal logic", Informal Logic, 24 (3). https://ojs.uwindsor.ca/ojs/leddy/index.php/informal_logic/article/ view/2147.

Gilbert, M.. A. (1999) "Language, words and expressive speech acts", Proceedings of the Fourth International Conference of the Intern ational Society for the Study of Argumentation, 15, 231-234. http://www.academia.edu/download/33164917/ mag1999-lang-wds.pdf.

Groarke, L. (2010) "Emotional arguments: ancient and contemporary views", International Society for the Study of Argumentation (ISSA) Conference 2010. http:// scholar.uwindsor.ca/philosophypub/35/.

Haidar Diab, H. (2016) “Assad pozvao Inu da se vrati na naftna polja”, Večernji list. https://www.vecernji.hr/vijesti/assad-pozvao-inu-da-se-vrati-na-naftna-polja-1076392.

Halmi, A., Belušić, R. i J. Ogresta, (2004) “Socijalnokonstruktivistički pristup analizi medijskog diskursa". Medijska istraživanja, 10 (2), 35-50.

Herbst, Ph. (2003). Talking terrorism: a dictionary of the loaded language of political violence. Westport, CT: Greenwood Press.

Herman, E. i N. Chomsky (1988) Manufacturing Consent. https://chomsky.info/ consent $01 \%$.

Ivas, I. (1988) Ideologija u govoru. Zagreb: Hrvatsko filozofsko društvo. 
Jäger, S. (2004) Kritische Diskursanalyse. Eine Einführung. Münster: Edition DISS. Jäger, S. (2007) "Diskurs als "Fluss von Wissen durch die Zeit". Ein transdisziplinäres politisches Konzept zur Deutung gesellschaftlicher Wirklichkeit", 1537. U: Siegfried J.: Deutungskämpfe. Theorie und Praxis kritischer Diskursanalyse. Wiesbaden : VS-Verlag für Sozialwissenschaften.

Jakobsen, P. V. (2000) "Focus on the CNN Effect Misses the Point: The Real Media Impact on Conflict Management is Invisible and Indirect", Journal of Peace Research, 37 (2).

Kunczik, M. (2006) Odnosi sjavnošću: koncepti i teorije. Zagreb: Fakultet političkih znanosti.

Mayring, Ph. (2015) Qualitative Inhaltsanalyse. Grundlagen und Techniken. Basel: Beltz.

Ramsenthaler, Ch. (2013) "Was ist „Qualitative Inhaltsanalyse”, 23-42. U: Schnell M. et al.: Der Patient am Lebensende, Palliative Care und Forschung. Wiesbaden: Springer Fachmedien.

Napoleoni, L. (2015) Uspon islamizma. Zagreb: Sandorf.

Rupčić, M. (2007) “Uloga glasina u ratu”, Polemos (10) 1, 63-72.

Šiber, I. (2003) Politički marketing. Zagreb: Politička kultura.

Škarica, M. (2012) Propaganda kroz europsku povijest. Zagreb - Sarajevo: Synopsis.

Taylor, Ph. M. (2009) "Novinarstvo pod paljbom”. U: S. Cottle: Informacije, odnosi s javnošću i moć. Zagreb: Naklada Medijska istraživanja.

Trapp, R. (2017) "The Use of Chemical Weapons in Syria: Implications and Consequences". U: B. Friedrich et al.: One Hundred Years of Chemical Warfare: Research, Deployment, Consequences. Springer International Publishing.

Van Dijk, T. (1988) Discourse as Structure and Process. London, Thousand Oaks, New Delhi: SAGE.

Van Dijk, T. (1998) Discourse as Social Interaction. London, Thousend Oaks, New Delhi: SAGE.

Van Dijk, T. (2006) "Discourse and Manipulation", Discourse and Society, 17 (2), 359-383.

Vuletić, B. (2006) Gramatika govora. Zagreb: Grafički zavod Hrvatske.

Vuletić, B. (2007) Lingvistika govora. Zagreb: Filozofski fakultet Sveučilišta u Zagrebu.

Weston, A. (2000) A Rulebook for Arguments. Indianapolis: Hackett Publishing Company. 
Analiza odabranih članaka o napadu kemijskim oružjem u Siriji u hrvatskim...

Wodak, R. i M. Meyer (2009) "Critical discourse analysis: history, agenda, theory, and methodology", 1-33. U: Wodak, R. i M. Meyer: Methods for Critical Discourse Analysis. London: Sage.

Zgrabljić, N. (2003) "Hrvatska medijska politika i javni mediji", Medijska istraživanja, 9 (1), 59-75.

\section{Internetski izvori:}

Agencija za elektroničke medije. www.e-mediji.hr.

Astroturfing. http://www.urbandictionary.com/define.php?term=astroturfing.

Bild. http://www.bild.de/politik/aktuelles/politik-ausland/aktivisten-mindestens58-tote-bei-giftgasangriff-51144354.bild.html.

Bild. http://www.bild.de/politik/ausland/syrien-krise/angriff-auf-assad-51190392. bild.html.

Bild. http://www.bild.de/politik/ausland/politik/politik-eilmeldung-syrien-51289166. bild.html

Chicago Tribune. http://www.chicagotribune.com/ct-syria-gas-attack-death-toll20170404-001-photo.html.

Das Statistik-Portal. https://de.statista.com/statistik/daten/studie/154154/umfrage/ anzahl-der-visits-von-nachrichtenportalen/.

Der Spiegel. http://www.spiegel.de/politik/ausland/syrien-raketenangriff-aufklinik-mit-mutmasslichen-giftgas-opfern-a-1141800.html.

Der Spiegel, http://www.spiegel.de/politik/ausland/syrien-usa-greifen-luftwaffenbasis-der-syrischen-armee-an-a-1142256.html.

Der Spiegel, http://www.spiegel.de/politik/ausland/baschar-al-Assad-chemiewaffenangriff-in-syrien-zu-hundert-prozent-konstruiert-a-1143295.html.

European Commission. https://eeas.europa.eu/sites/eeas/files/action_plan_against_ disinformation.pdf.

Focus ONLINE. http://www.focus.de/politik/ausland/konflikte-aktivisten-mindestens-58-tote-bei-giftgasangriff-in-syrien_id_6890862.html.

Focus ONLINE, http://www.focus.de/politik/ausland/usa/trump-macht-drohungwahr-usa-feuern-raketen-auf-luftwaffenbasis-in-syrien-ab_id_6909256.html.

Focus ONLINE, http://www.focus.de/politik/ausland/assad-behauptet-chemiewaffenangriff-zu-hundert-prozent-konstruiert_id_6955021.html.

Die Welt. https://www.welt.de/politik/ausland/article163418959/Familien-sind-inihren-Betten-gestorben.html.

Die Welt. https://www.welt.de/politik/ausland/article163499305/Luftwaffenstuetzpunkt-al-Schairat-in-Stuecke-gerissen.html.

Die Welt. https://www.welt.de/politik/ausland/article163686232/Assad-nennt-Giftgasangriff-zu-100-Prozent-konstruiert.html. 
Medij. istraž. (god. 25, br. 1) 2019. (5-31)

Die Zeit. http://www.zeit.de/politik/ausland/2017-04/syrien-krieg-giftgasangriffkonferenz-bruessel-kristin-helberg-interview.

Die Zeit. http://www.zeit.de/politik/ausland/2017-04/usa-greifen-syrischen-luftstuetzpunkt-mit-raketen-an.

Die Zeit. http://www.zeit.de/politik/ausland/2017-04/baschar-al-Assad-syrien-interview-giftgas-vorwurf-konstruiert-freisetzung-us-angriff-vorwuerfe.

In Video Veritas - Verification of Social Media Video Content for the News Industry. http://cordis.europa.eu/project/rcn/199134_en.html.

Jutarnji list. www.jutarnji.hr/vijesti/svijet/stravican-masakr-kemijskim-oruzjem-usiriji-u-zracnim-napadima-na-polozaje-pobunjenika-ubijeno-najmanje-58-osoba-zrtvama-izlazila-pjena-na-usta/5858415/.

Jutarnji list. www.jutarnji.hr/vijesti/svijet/trumpova-osveta-Assadu-poceo-americki-napad-na-siriju-s-ratnih-brodova-u-sredozemnom-moru-ispaljene-krstarece-rakete-prema-Assadovoj-zracnoj-bazi/5874306/.

Novi list. www.novilist.hr/Vijesti/Svijet/Zrtve-povracale-i-gusile-se-Bojni-otrovibaceni-na-sjeverozapadu-Sirije-medu-ubijenima-i-djeca.

Novi list. http://novilist.hr/index.php/layout/set/print/Vijesti/Svijet/Americka-veleposlanica-pri-UN-u-Moguci-novi-napadi-na-Siriju.

Novi list. www.novilist.hr/Vijesti/Svijet/Assad-Kemijski-napad-u-Idlibu-izmisljotina-uopce-nemamo-takvo-oruzje.

Slobodna Dalmacija. www.slobodnadalmacija.hr/novosti/svijet/clanak/id/478858/ zbog-kemijskog-napada-u-siriji-zasjeda-vijece-sigurnosti-rusija-se-protivi-nacrtu-rezolucije.

Slobodna Dalmacija. www.slobodnadalmacija.hr/novosti/svijet/clanak/id/479146/ svijet-podijeljen-nakon-americkog-napada-na-siriju-moskva-bjesni-ovo-je-aktagresije-na-clanicu-un-a

Večernji list. www.vecernji.hr/vijesti/najmanje-58-ljudi-ubijeno-u-zracnim-napadima-na-pobunjenicka-podrucja-na-sjeverozapadu-sirije-1160877.

Večernji list. www.vecernji.hr/vijesti/sad-izveo-napad-na-zracnu-bazu-u-siriji-ispalili-59-projektila-stigle-osude-rusije-1161601.

Večernji list. www.vecernji.hr/vijesti/svjetska-ekskluziva-al-Assad-europa-se-necezastititi-od-terorista-jer-ih-podrzava-1161321.

24sata. www.24sata.hr/news/napali-su-ih-otrovnim-plinom-ljudima-na-usta-izlazila-pjena-518791 - 24sata.hr.

24sata. www.24sata.hr/news/trump-naredio-napad-na-siriju-taj-se-pokolj-morazaustaviti-519251 - 24sata.hr.

24sata. www.24sata.hr/news/mi-nemamo-kemijsko-oruzje-a-taj-napad-je-cistaizmisljotina-520213 - 24sata.hr. 


\title{
Analysis of Selected Articles Regarding Chemical Attack in Syria in Croatian and German Electronic Media
}

\author{
Mirela Holy \\ Nikolina Borčić \\ Diana Tomić
}

\section{SUMMARY}

The war in Syria is a major threat to the global security, intertwined field of crucial geopolitical interests of super-power states - the USA and Russia and their allies. Russia politically and military supports the regime of Syrian President al-Assad against the rebels, while the position of the United States and NATO members is ambivalent, simultaneously they condemn undemocratic regime of Syrian President and demand his recall as well as the terrorist threat of ISIS that fused with the Syrian rebel movement. Use of chemical weapons in Syria in April 2017 could led to open conflict between USA plus NATO allies and Russia, and that is also visible through their propaganda activities in the media. Given the fact that the 'manufacturing of consent'for political solutions is usually achieved with propaganda, the paper analyses content of electronic media on the subject of chemical weapons attack in Syria in two NATO members, Germany and Croatia, especially the possibility of propaganda usage when reporting on three events or pseudo-events associated with the usage of chemical weapons.

Key words: Syria, chemical weapons, Croatia, Germany, war propaganda, media 
